\title{
TEACHING RECOUNT TEXT THROUGH SCRABBLE GAME
}

\author{
Siti Shopiah $^{1}$, Resi Anggraeni \\ IKIP Siliwangi ${ }^{1}$ \\ IKIP Siliwangi ${ }^{2}$ \\ 1'sitishopiah12@gmail.com , ${ }^{2}$ resianggraeni13@gmail.com
}

\begin{abstract}
This research is aimed to identify whether scrabble game can improve students' new vocabulary in recount text at eighth grade of junior high school. This research was conducted in SMPN 39 Bandung. The research was conducted by using quantitative research design, and pre-experimental research method. The researcher used one-group pretest-posttest design. The sample of this research was the eighth grade students of SMPN 39 Bandung, which consist of 32 students. In collecting the data, the researcher used test. The results of this research show that the scrabble game is able to improve students vocabulary in recount text. It is proved by the significant value using SPSS statistics 21 version to analyze the data by normality test, homogeneity and T-test. Through the normality test, the significant showed $0,090>0,05$ and 0,061>0,05 which means that the data was normal. The data also homogeny with $0,348>0,05$ as the significant value. Moreover, the T-test also showed that the significant value was $0,000<0,05$ which means that the null hypothesis $\left(\mathrm{H}_{0}\right)$ was rejected. In conclusion, applying scrabble game in teaching recount text is recommended because there is significant effect of scrabble game to students in teaching recount text.
\end{abstract}

Keywords: Recount text, scrabble game

\section{INTRODUCTION}

In learning English language, every language learner needs to master the language skills, such as listening, speaking, reading, and writing. The first thing that should be mastered is vocabulary. All skills that can be applied to the type of the text, one of them is recount text. According to Evans (2013) "recount is a chronological retelling of events". Most of students had difficulties in telling recounts, one of which is the lack of vocabulary. The need of being accurate in telling recount, especially making the students able to tell their experience or event, students have to know the language features of recount. However, they still found difficulties with vocabulary as well as in putting their ideas following the generic structure of recount text with which they can tell something accurately and appropriately.

Talking about technique in teaching recount text, there are many techniques to find new vocabulary in recount text. One of them is game. Games involve of imagined, ritual, competition, and luck that are interesting for students. It means that games reduce boredom. When games are used, the situations of classroom become life and natural Games create situations that make students need and want to use English. One of the games which appropriate in teaching recount text is scrabble game. Scrabble is a word game that can play for two, three, or four players. To play it, consists of forming interlocking words, cross word fashion on the scrabble playing board using letter tiles with various score values. In general, scrabble can be defined as a board game in which the player tries to make the words 
of the letter printed on a small plastic block and attach it to a place on the board. Using scrabble game in teaching recount text will make it easier for students to create recount text.

Based on the description above, this study highlights the technique in teaching recount text

\section{Recount Text}

A recount text is a kind of text to retell the series or events which happened to the participant in the past. According to Gerot and Wignell (1994) a recount text retells an experience for telling as well as entertaining the readers. In addition, based on Anderson (1998) recount is a piece of text that retells events aimed to give the audience a description of what happened and when it happened. Moreover, according to Hyland (2004) recount is a kind of category that has social function to retell experience for the purpose of expressive or entertaining. Recounts are the simplest text type in this genre. Formally, recounts are sequential texts that do little more than sequence a series of events.

\section{Types of Recount Text}

According to Derewianka (1990), there are five types of recount text.

a. Personal recount is a recount that retelling of an activity that writer or speaker has been personally involved in (e.g. oral anecdote, diary entry). Language features of personal recount are:

1. Use first pronoun (I and we).

2. Personal response to the events can be included, particularly at the end.

3. Details are often chosen to add interest or humor.

b. Factual recount is a recount that recording the particulars of an accident, e.g. report of a science experiment, police report, news report, and historical recount). Language features of factual recount are:

1. Use the third person pronouns (he, she, it, and they).

2. Details are usually selected to help the reader reconstruct the activity or incident accurately.

3. Sometimes the ending describes the outcome of the activity Mention of personal feelings in probably not appropriate.

4. Details of time, place, and manner may be needed to be precisely stated.

5. Descriptive details may also be required to provide precise information the passive voice may be used It may be appropriate to include explanations and satisfactions.

c. Imaginative or literary recounts entertains the reader by recreating imaginary world events as if they were real, motion language, specific detail and first person narration are used to impact and appeal the writing.

d. A procedural recount records the steps taken in completing a task or procedure. The use of technical terms, accurate timelines and first person narration (I or we), give credibility to the information provided. Examples include a flow chart of the actions required for making bread, a storyboard, a videotaped script, or advertisement, the stepstaken to solve mathematical problem.

e. A biographical recount tells the story of person's life using a third person narrator (he, she, and they). In this case, of an autobiography, first person narration (I, we) is used. It is usually informative and factual biographies, however, will not have the appeal provided by personal responses and unforgettable anecdotes. There is often evaluation of the subject's achievements in the final section. 


\section{Scrabble Games}

Srabble game is very good media to teach english in classroom because it makes challenges students ability to remember vocabulary more enjoyable. According to Warner \& Brown (in Rosidi \& Falianti, 2014) Scrabble is a branded board game, which involves the structure of words for point scores, for two or more players (or teams). In addition, Simmons (2016) states that scrabble is considered a game where luck plays an important role in determining whether you have good or bad letters on your shelf.

\section{METHOD}

The researchers used pre-experimental method as research method. The researchers used numerical data and statistical to describe the findings of the research. This research took the eight grade students of SMPN 39 Bandung as the pop ulation, which consisted of 248 students in eight classes and took one class of eighth grade students of as sample, which consisted of 32 students. For collecting the data the researchers use test; pre-test and post-test. In analyzing data, the researchers use SPSS.

\section{RESULTS AND DISCUSSION}

\section{Results}

To collect data in this research, the writers used pre experimental one-group pretest- posttest design, the pretest was conducted on January $22^{\text {nd }} 2018$ to the eighth grade of SMPN 39 Bandung. After giving the pretest, the writer conducted treatment to teaching recount text through scrabble game. After doing with the treatment, the students were given posttest. It was conducted on February $5^{\text {th }} 2018$.

The data of students' pretest and posttest score can be seen in the following table:

Table 4.1

Students' Pretest and Posttest

\begin{tabular}{llccc}
\hline No & Name & Pretest & Posttest & Gain Score \\
\hline 1 & Student 1 & 50 & 50 & 0 \\
\hline 2 & Student 2 & 40 & 50 & 10 \\
\hline 3 & Student 3 & 80 & 70 & 10 \\
\hline 4 & Student 4 & 90 & 80 & 10 \\
\hline 5 & Student 5 & 70 & 80 & 10 \\
\hline 6 & Student 6 & 90 & 80 & 10 \\
\hline 7 & Student 7 & 60 & 80 & 20 \\
\hline 8 & Student 8 & 100 & 100 & 0 \\
\hline 9 & Student 9 & 70 & 70 & 0 \\
\hline 10 & Student 10 & 80 & 90 & 10 \\
\hline 11 & Student 11 & 50 & 60 & 0 \\
\hline 12 & Student 12 & 70 & 70 & 10 \\
\hline 14 & Student 13 & 70 & 60 & 0 \\
\hline 15 & Student 14 & 80 & 90 & 10 \\
\hline 16 & Student 15 & 80 & 80 & 20 \\
\hline 17 & Student 16 & 40 & 50 & 50 \\
\hline
\end{tabular}




\begin{tabular}{llccc}
\hline 18 & Student 18 & 40 & 70 & 30 \\
\hline 19 & Student 19 & 40 & 40 & 0 \\
\hline 20 & Student 20 & 60 & 80 & 20 \\
\hline 21 & Student 21 & 30 & 40 & 10 \\
\hline 22 & Student 22 & 50 & 70 & 20 \\
\hline 23 & Student 23 & 90 & 100 & 10 \\
\hline 24 & Student 24 & 30 & 30 & 0 \\
\hline 25 & Student 25 & 40 & 60 & 20 \\
\hline 26 & Student 26 & 60 & 70 & 10 \\
\hline 27 & Student 27 & 80 & 80 & 0 \\
\hline 28 & Student 28 & 100 & 90 & 10 \\
\hline 29 & Student 29 & 90 & 100 & 10 \\
\hline 30 & Student 30 & 30 & 40 & 10 \\
\hline 31 & Student 31 & 90 & 80 & 10 \\
\hline 32 & Student 32 & 50 & 60 & 10 \\
\hline
\end{tabular}

It can be seen from the table, the highest score of pretest was 100 and the lowest score was 30. There were two students who get 100 for the highest score, and four students who get 30 for the lowest score in pretest. The highest score of posttest was 100 and the lowest score was 30. Three students get 100 for the highest score, and one student get 30 for the lowest score in posttest. It can be concluded that after doing the treatment there was improvement of students score in posttest.

Before the data presented, the descriptive score of pretest and posttest is on the table below:

Table 4.2

Descriptive Statistics

\begin{tabular}{|c|c|c|c|c|c|}
\hline & $\mathrm{N}$ & Minimum & Maximum & Mean & Std. Deviation \\
\hline Pretest & 32 & 30 & 100 & 63.44 & 22.520 \\
\hline Posttest & 32 & 30 & 100 & 69.38 & 18.826 \\
\hline $\begin{array}{l}\text { Valid N } \\
\text { (listwise) }\end{array}$ & 32 & & & & \\
\hline
\end{tabular}

Based on the table 4.2 can be seen that mean of posttest bigger than pretest, posttest is 69,38 , meanwhile pretest is 63,44 .

The data then analyzed using Kolmogorov - Smirnov test to identify the normality because the researcher takes sample 32 students more than 30 students.

Table 4.3

Tests of Normality

\begin{tabular}{lcccccc}
\hline & \multicolumn{3}{c}{ Kolmogorov-Smirnov } & \multicolumn{3}{c}{ Shapiro-Wilk } \\
\cline { 2 - 7 } & Statistic & df & Sig. & Statistic & Df & Sig. \\
\hline Pretest & .144 & 32 & .090 & .925 & 32 & .029 \\
Posttest & .151 & 32 & .061 & .953 & 32 & .180 \\
\hline
\end{tabular}

a. Lilliefors Significance Correction

Based on the table 4.3, can be seen that the significance value of pretest is 0,090 and posttest is 0,061 more than 0.05 , which means that the data was normally distributed. 
Table 4.4

Test of Homogeneity of Variances

Pretest

\begin{tabular}{cccc}
\hline $\begin{array}{c}\text { Levene } \\
\text { Statistic }\end{array}$ & df1 & df2 & Sig. \\
\hline 1.184 & 6 & 24 & .348 \\
\hline
\end{tabular}

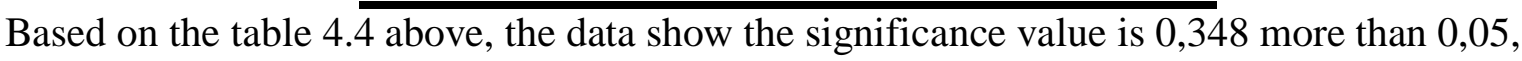
which means that the data was homogeneous.

Table 4.5

One-Sample Test

\begin{tabular}{lcccccc}
\hline & \multicolumn{7}{c}{ Test Value $=0$} \\
\cline { 2 - 7 } & $\mathrm{T}$ & $\mathrm{df}$ & $\begin{array}{c}\text { Sig. }(2- \\
\text { tailed) }\end{array}$ & $\begin{array}{c}\text { Mean } \\
\text { Difference }\end{array}$ & $\begin{array}{c}\text { 95\% Confidence Interval } \\
\text { of the Difference }\end{array}$ \\
\cline { 3 - 7 } & & & .000 & 63.438 & 55.32 & 71.56 \\
Pretest & 15.935 & 31 & .000 & 69.375 & 62.59 & 76.16 \\
\hline Posttest & 20.845 & 31 & Lower & Upper \\
\hline
\end{tabular}

The table 4.5 above shows that through T-test, the significant value of the pretest was 0,000 and the posttest was 0,000 . It means the significance less than 0,05 . Based on the result, it can be conclude that Ho was rejected and Ha was accepted.

\section{Discussion}

Based on the data analysis, it can be seen that from table 4.2 the data was normal. The researchers use Kolmogorov-smirnov because the sampel is more than 30.The significance value of pretest and posttest in Kolmogorov-Smirnov test was 0,200 which more than 0,05. Therefore, it can be implied that the data was normal distributed. Furthermore, based on the table 4.3 it showed that the result of the significance was 0,056 which more than 0,05 . It can be concluded that the data of this research was homogeneous. Then, the researcher also used T-Test to analyze the data on table 4.4 that showed the significance of the pretest was 0,000 and the posttest was 0,000 . It means that the Ho is rejected. Thus, based on the statistic process using SPSS above, it can be concluded that teaching recount text through scrabble game was effective because there was a significance changes between pretest mean and posttest mean.

\section{CONCLUSION}

Based on the data research findings, it can be concluded that scrabble game is effective in teaching recount text. The research method used quantitative research and the research designed used pre experimental method. Specifically the one group pretest-posttest designs which consists 32 students and the test as the instrument. The result of normality test is normal. It caused the significance value more than 0.05 . Moreover, the result of homogeneity test is homogen. It caused the significance value more than 0,05 . Then, the researcher also used T-Test to analyze the data that showed the significance of the pretest was 0,000 and the posttest was 0,000 . It means that the Ho is rejected. 


\section{ACKNOWLEDGMENTS}

Alhamdulilahirobbil 'alamin, praise for Allah SWT for all the blessing and grace to enable us to complete this journal entitled: Teaching Recount Text through scrabble game at the eight grade student of SMPN 39 Bandung. This journal is a requirement for accomplishing S-1 degree in English Education department, IKIP Siliwangi, Cimahi.

The researchers greatest appreciation also goes to Dr. Irma Savitri Sadikin M. Pd as The Head of English Education Study Program. We also want to deliver my sincere thank to Intan Satriani, M.pd as our advisor. Thank you for all your suggestions and guidance which are useful to finish our journal. We also thank to all my lecturers in English Education Program for all your time to share your knowledge.

\section{REFERENCES}

Anderson, M., \& K, A. (1998). Text types in English. South Yarra: Macmillan Education Australia.

Derewianka, B. (1990). Exporing How Text Works. Newton, NSW: Primarily English Tecahing Association.

Evans, P. (2013). How To Teach Non-Fiction Writing at Key Stage 3. New York: David Fulton.

Gerot, L., \& W. (1994). Making Sense of Functional Grammar. Sydney: Macquirie University.

Hyland, K. (2004). Genre and Second Language Writing. The United States of America: The University of Michigan Press.

Rosidi, A., \& Falianti, E. (2014). The Effectiveness Of Using Scrabble And Bingo Game Technique Toward Students' Vocabulary Mastery At The Tenth Grade Of SMAN 2 Metro Academic, Year 2013/2014, 3 No 2.

Simmons, A. (2016). Scrbble Trainer. New York: Harper Collin. 